\begin{tabular}{|c|c|c|}
\hline Beitr. Ent. & Keltern & ISSN 0005-805X \\
\hline $\mathbf{5 7}(2007) 1$ & S. $81-91$ & 30.06 .2007 \\
\hline
\end{tabular}

\title{
Notes on Anomala felicia Arrow, 1910 and its relatives from Borneo with descriptions of six new species
}

\section{(Coleoptera: Scarabaeidae: Rutelinae)}

With 22 figures and 1 distribution map

\section{Carsten Zorn}

\section{Summary}

The type material of Anomala felicia Arrow, 1910, Anomala kinabalensis OHAus, 1916 and Anomala sarawakensis OHaus, 1916 is revised. Lectotypes are selected for the nominal taxa Anomala felicia Arrow, 1910 and Anomala ovatula kinabalensis OHaus, 1910. Anomala snizeki sp. n., Anomala kaltengensis sp. n., Anomala bifida sp. n., Anomala aequalis sp. n., Anomala mahakamensis sp. n. and Anomala manseri sp. n. are described as new to science.

\section{Zusammenfassung}

Das Typenmaterial von Anomala felicia Arrow, 1910, Anomala kinabalensis OHAus, 1916 und Anomala sarawakensis OHAus, 1916 wird revidiert. Für die nominellen Taxa Anomala felicia Arrow, 1910 und Anomala ovatula kinabalensis OHaus, 1910 werden Lectotypen designiert. Anomala snizeki sp. n., Anomala kaltengensis sp. n., Anomala bifida sp. n., Anomala aequalis sp. n., Anomala mahakamensis sp. n. und Anomala manseri sp. n. werden als neue Arten beschrieben.

\section{Keyword}

Coleoptera, Scarabaeidae, Rutelinae, Anomala, taxonomy, new species, Oriental region, Borneo

\section{Introduction}

More than 60 Anomala species are described or recorded from Borneo of which the majority are island endemites. Only few of the Bornean Anomala species can be found also on Sumatra, Java or in West Malaysia. Another distribution pattern includes Borneo, Palawan and the Philippine islands (e. g. A. sulcatula Burmeister, 1844). Most of the Bornean Anomala species were described from Sarawak and Sabah whereas material from the larger Indonesian part of the island (Kalimantan) is underrepresented in most collections. Thus, the low sampling intensity in Kalimantan does not permit final conclusions concerning the distribution pattern of the species treated in this paper (Fig. 22).

Ohaus (1910) described A. kinabalensis and A. sarawakensis, two of the species treated here, as subspecies of the Philippine Anomala ovatula OHAus, 1910a but apart from a superficial similarity the latter is not closely related to these species. Later, Ohaus raised A. kinabalensis and A. sarawakensis to specific rank (OHAus, 1916) and recognized their close relationship with A. felicia and provided a short identification key to these three species (OHAus, 1938). In the 
course of the examination of the unidentified Anomala material of several European museums and personal collecting activities in Kalimantan six new species related to the three above mentioned were discovered. In this paper these new species are described and revisions of the known taxa of the $A$. felicia species group are provided.

\section{Material}

The material cited in this publication is deposited in the following collections:

$\begin{array}{ll}\text { BMNH } & \text { Natural History Museum, London } \\ \text { DEI } & \text { Deutsches Entomologisches Institut, Müncheberg } \\ \text { ZMHB } & \text { Museum für Naturkunde der Humboldt-Universität, Berlin } \\ \text { NHMB } & \text { Naturhistorisches Museum, Basel } \\ \text { RMNH } & \text { National Museum of Natural History, Leiden } \\ \text { MTD } & \text { Museum für Tierkunde, Dresden } \\ \text { ZMAN } & \text { Zoölogisch Museum Amsterdam, Amsterdam } \\ \text { CCZ } & \text { Collection C. Zorn, Gnoien } \\ \text { CDK } & \text { Collection Denis Keith, Chartres }\end{array}$

Type specimens of the newly described species are provided with one printed red label: „Holotype [Paratype] Anomala [species' name] sp. n. det. Zorn, 200x“.

\section{Taxonomy}

Anomala felicia Arrow, 1910 (Fig. 23)

Anomala felicia ARrow, 1910: 69 [description]

Lectotype (here designated): “` „Type | Whitehead | Borneo Kina Balu | Fry Coll. 1905-100. | Anomala felicia, Arrow Type" (BMNH).

Paralectotypes: $10^{\star}$ „Whitehead | 68259 | Borneo Kina Balu | Fry Coll. 1905-100.“(BMNH). $10^{\star}$ „Whitehead; Borneo Kina Balu; Fry Coll. 1905-100.; Anomala felicia, Arrow Cotype“ (BMNH). [=Anomala kinabalensis Ohaus, 1910]; 1 ㅇ „Whitehead | Borneo Kina Balu | Fry Coll. 1905100." (BMNH). [uncertain species identity].

Note: Because the type series is not monospecific a lectotype designation was necessary.

Additional material: $10^{\star}, 1$ ㅇ „Kinabalu Borneo“ (NHMB). $10^{\star}$ „BORNEO, Sabah W., Crocker Range, W

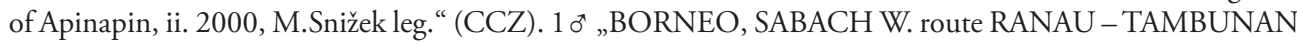
2.2000 Ltg. Snižek“ (CCZ). 1 o”, 1 ㅇ „BORNEO Sabah Crocker Range Keningau V.93 LEGRAND leg.“ (CDK).

\section{Redescription:}

Body shape. Elongate ovoid; length. 9.2-10.3 mm; width. 5.1-5.5 mm. Color. Dorsal face, abdominal sternites (except the last one in $\sigma^{\top} \sigma^{\top}$ ), tibiae and tarsi reddish brown with metallic green shine; ventral face including the femora, pygidium and antennae brownish yellow; lateral parts of the pronotum yellow; inner limitation of the yellow lateral band notched in the middle (Fig. 19); laterobasal part of pygidium sometimes darkened. Head. Clypeus trapezoid; clypeus and frons with sometimes confluent, rather coarse punctures; vertex finely and not densely punctate; clavus 
distinctly shorter than antennomeres 1-6 combined but longer than the funiculus. Pronotum. Ca. $1.7 \mathrm{x}$ as broad as long, widest at base; sides subparallel in the posterior half, strongly convergent in the anterior half; anterior angles square; posterior angles obtuse and narrowly rounded; basal bead not interrupted; punctation fine and moderately dense on disc; punctures separated by 1-2(3) diameters. Scutellum. Punctured like the disc of the pronotum. Elytra. With regular, impressed striae; intervals slightly elevated; 2 nd and 3rd interstice with interrupted and not impressed secondary striae; subsutural interstice irregularly punctured anteriorly, with an indistinct stria in the posterior half. Pygidium. With sparse, rather coarse, ocellated punctation; distal margin with erect setae. Metasternum. With well-separated, ocellated punctures and rather short and sparse setosity in the lateral part. Abdominal sternites. Sparsely punctured in the middle, with denser punctures laterally; with a transverse row of setae. Protibiae. Bidentate, terminal tooth shortly bent outwards; lateral tooth small, square. Metatibiae. Rather short, a little enlarged in the middle and constricted before the apex. Claws. Modified claw of the pro- and mesotarsi apically bifid, protarsi enlarged but with angle or tooth at the inner margin. Aedeagus. Figs 1-2.

\section{Diagnosis:}

Anomala felicia is easily separated from the other members of this species group by the shape of the aedeagus which is simple and not elongate as in the other species. Moreover, the inner limitation of the yellow lateral patch of the pronotum is notched in the middle (Fig. 19), not evenly broad from anterior to posterior angle or extremely narrowed in the posterior half.

Distribution: Anomala felicia is only known from the Kina Balu region in the province of Sabah (Fig. 22).

\section{Anomala snizeki sp. $\mathrm{n}$.}

Holotype: $0^{\star}$ „Museum Leiden Malaysia SABAH: Long Pa Sia: Banks of S. Pa Sia; sec veg. $4^{\circ} 25^{\prime} \mathrm{N}$ 11543’E. 1090 m 14-28 Oct 1986. J. Huisman | RMNH Leiden Loan 11454" (RMNH).

Paratypes: $2 \sigma^{\star} \sigma^{\star}$ „Museum Leiden Malaysia SABAH: Long Pa Sia: Banks of S. Pa Sia; sec veg. $4^{\circ} 25^{\prime} \mathrm{N} 115^{\circ} 43^{\prime} \mathrm{E} .1090 \mathrm{~m}$ 14-28 Oct 1986. J. Huisman| RMNH Leiden Loan $11454^{\prime \prime}$ $(\mathrm{RMNH}) .30^{\star} 0^{\star}$ „BORNEO, SABAH W. route RANAU - TAMBUNAN 2.2000 Ltg. Snizek“ (CCZ). $10^{\star}$ „N. Borneo. Bettotan, NR. SANDAKAN. Aug. 12th 1937 | Anomala kinabalensis Ohs.“ (NMHB). $10^{\star}$ „N. Borneo. Bettotan, NR. SANDAKAN. Aug; 12th 1937.| Anomala kinabalensis Ohs." (NMHB).

\section{Description and diagnosis:}

Length. 9.2-10.0 mm; width. 5.1-5.6 mm. Anomala snizeki shares most morphological characters with $A$. felicia as described above. The inner limitation of the yellow lateral band of the pronotum is not notched but usually straight from anterior to posterior margin (Fig. 20), a character that is shared with $A$. kaltengensis, $A$. bifida, $A$. aequalis, $A$. kinabalensis and $A$. mahakamensis. From these five species, $A$. snizeki can only be distinguished by the shape of the aedeagus. The parameres are strongly elongate whereas the ventral plate shows no extensions (Figs 3-4).

Distribution: Anomala snizeki is known from various localities in Sabah (Fig. 22).

Etymology: The species is named after Miroslav Snížek (České Budějovice) who collected some of the paratypes. 

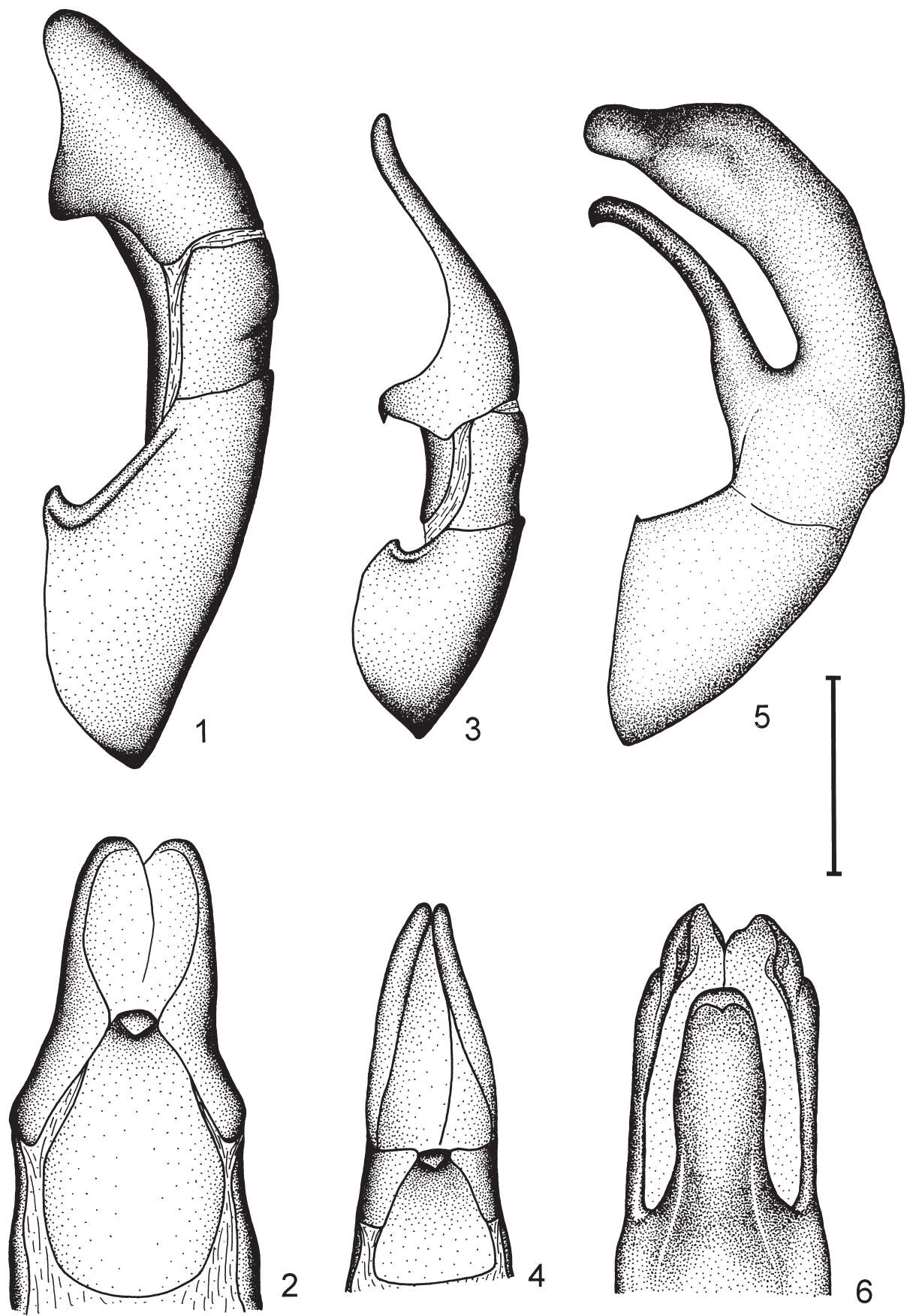

Figs 1-2: Aedeagus of Anomala felicia (lectotype); Fig. 1, lateral aspect; Fig. 2, ventral aspect. Figs 3-4: Aedeagus of Anomala snizeki (holotype); Fig. 3, lateral aspect; Fig. 4, ventral aspect. Figs 5-6: Aedeagus of Anomala kaltengensis (holotype); Fig. 5, lateral aspect; Fig. 6, ventral aspect. - scale $=1 \mathrm{~mm}$. 


\section{Anomala kaltengensis sp. $\mathbf{n}$.}

Holotype: $\sigma^{\star}$ „Indonesia Kalimantan Tengah, Tewah 23.II.96, secondary forest, leg. A. Kallies \& C. Zorn" (CCZ).

Paratypes: $10^{\star}, 1$ + - same data as holotype (CCZ).

\section{Description and diagnosis:}

Length. 9.2-10.3 mm, width. 5.1-5.5 mm. Anomala kaltengensis shares most morphological characters with $A$. felicia as described above. The inner limitation of the yellow lateral band of the pronotum is not notched but usually straight from anterior to posterior margin (Fig. 20), a character that is shared with $A$. bifida, $A$. snizeki, $A$. aequalis, $A$. kinabalensis and $A$. mahakamensis. From these five species, $A$. kaltengensis can only be distinguished by the shape of the aedeagus. The parameres and ventral plate are strongly elongate, the parameres are somewhat thickened apicad (Figs 5-6).

Distribution: Anomala kaltengensis is only known from the type locality Tewah in Central Kalimantan (Fig. 22).

Etymology: The species is named after the abbreviation "Kalteng" for the type locality, the province Kalimantan Tengah (Central Kalimantan).

\section{Anomala bifida sp. n.}

Holotype: $\overbrace{}^{\star}$ „Puak, Sarawak. G. E. Bryant. 5.V.14 | G. Bryant Coll. B.M.1926-86.“ (BMNH).

\section{Description and diagnosis:}

Length. $9.2 \mathrm{~mm}$; width. $5.3 \mathrm{~mm}$. Anomala bifida shares most morphological characters with A. felicia as described above. The inner limitation of the yellow lateral band of the pronotum is not notched but usually straight from anterior to posterior margin (Fig. 20), a character that is shared with $A$. snizeki, $A$. kaltengensis, $A$. aequalis, $A$. kinabalensis and $A$. mahakamensis. From these five species, $A$. kaltengensis can only be distinguished by the shape of the aedeagus. Both, parameres and ventral plate are strongly elongate, the parameres are apically pointed (Figs 7-8).

Distribution: Anomala bifida is only known from the type locality Puak in the province of Sarawak (Fig. 22).

Etymology: The epithet is referring to the deeply incised parameres found in this species.

\section{Anomala aequalis sp. $\mathrm{n}$.}

Holotype: $\sigma^{\star}$ „Ouest Borneo Deby | Coll.et determ. J.La Fontaine. | Coll. Kraatz | Ohaus det.“ (DEI).

\section{Description and diagnosis:}

Length. $9.6 \mathrm{~mm}$; width. $5.6 \mathrm{~mm}$. Anomala aequalis shares most morphological characters with A. felicia as described above. The inner limitation of the yellow lateral band of the pronotum is not notched but usually straight from anterior to posterior margin (Fig. 20), a character that is shared with $A$. snizeki, $A$. kaltengensis, $A$. bifida, $A$. kinabalensis and $A$. mahakamensis. From these five species, $A$. aequalis can only be distinguished by the shape of the aedeagus. Both, parameres and ventral plate are strongly elongate. The parameres are apically not pointed nor angled (Figs 9-10). 


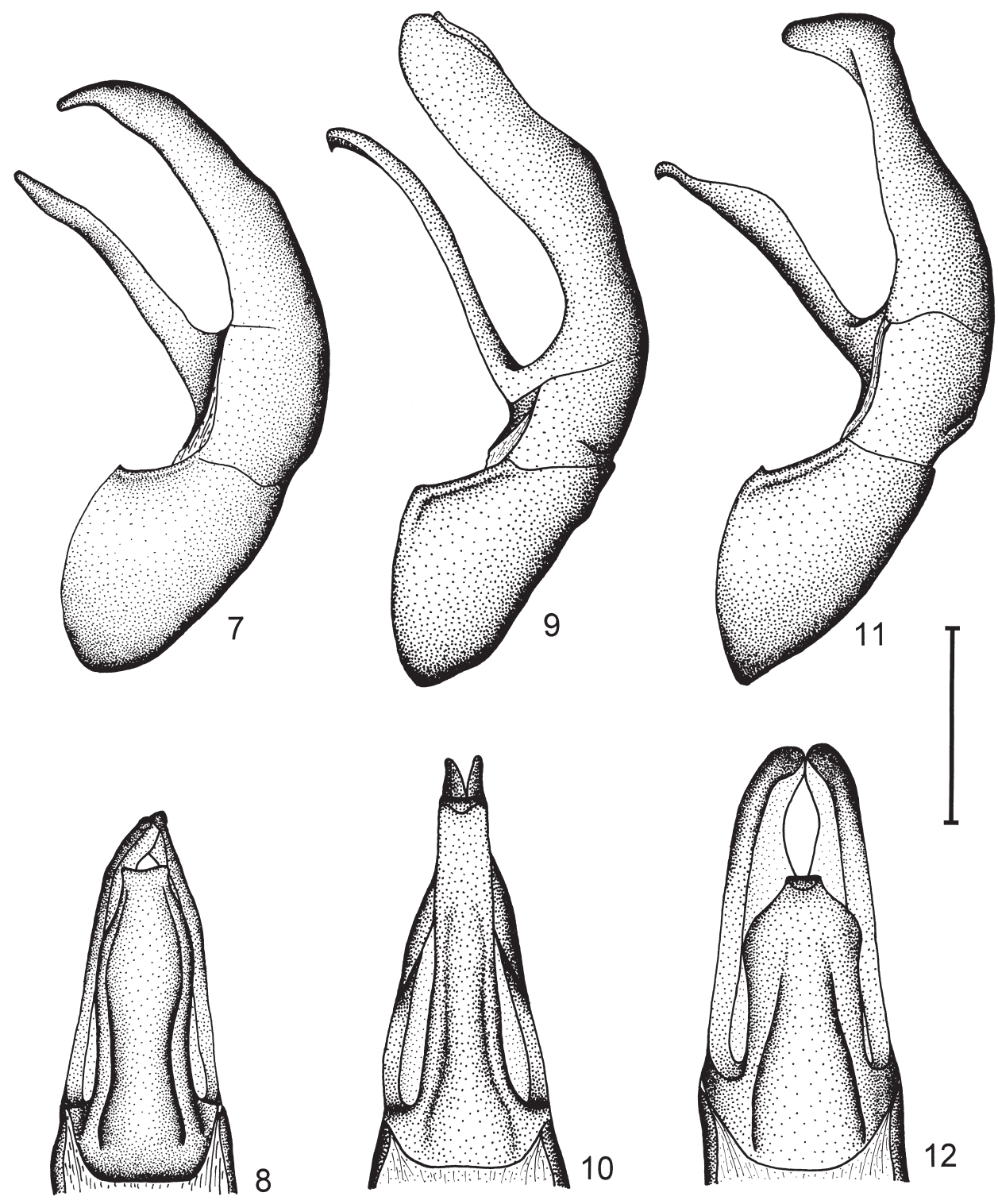

Figs 7-8: Aedeagus of Anomala bifida (holotype); Fig. 7, lateral aspect; Fig. 8, ventral aspect. Figs 9-10: Aedeagus of Anomala aequalis (holotype); Fig. 9, lateral aspect; Fig. 10, ventral aspect. Figs 11-12: Aedeagus of Anomala kinabalensis (Sabah, Kinabalu); Fig. 11, lateral aspect; Fig. 12, ventral aspect. - scale $=1 \mathrm{~mm}$.

Distribution: Anomala aequalis is only known from the imprecise type locality, West Borneo (Fig. 22).

Etymology: The species name was chosen because $A$. aequalis cannot be distinguished by external characters from most of its relatives but can only be differentiated by the shape of the aedeagus. 
Anomala kinabalensis OHAUs, 1910

Anomala ovatula kinabalensis OHAus, 1910b: 216 [description]; OHAus 1916: 54 [Anomala kinabalensis]

Lectotype (here designated): $10^{\star}$ "N.BORNEO Kina Balu Waterstraat | Anomala kinabalensis Ohs. Type" (NMHB).

Paralectotype: 1 ㅇ "N.BORNEO Kina Balu Waterstraat | Anomala kinabalensis Ohs. Cotype" (NMHB).

Note: Because it is not entirely certain that the type series is monospecific a lectotype designation was necessary.

Additional material: 1 ㅇ "BORNEO Grubauer |Anomala kinabalensis Ohs. Cotype" (NMHB). $10^{\text {A }}$ "Limbang 12-2-10 | Anomala sarawakensis Ohs. Cotype" (NMHB). $100^{\star} 0^{\star}, 3$ 우 우 "N. Borneo Brunei Waterstradt S."

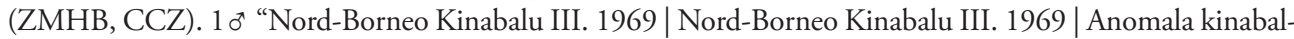
uensis Ohs. det. G. Frey, 1967/68" (NHMB). 1 \% "Borneo | Ohaus determin. Anomala kinabalensis Ohs." (NHMB). $10^{\text {t }}, 3$ 우 ㅇ "Sabah: Sook, 1500ft. 17m.SW Keningau, 15.viii.1977| At light | M. E. Bacchus B.M.1978-48” (BMNH). 1 ㅇ "SABAH:Mt.Kinabalu Tenom Keningau 4-8.iii.1964.J.Smart. Royal Soc.Exped. B.M.1964-250" (BMNH). $30^{\star} 0^{\star}$ "Borneo | Museum Leiden verz.F.T. Valck Lucassen | Anomala kinabalensis Ohs. det.Ohaus 1928” (RMNH). 10", 1 "Kinabalu, Borneo,1500m H.Rolle, Berlin S.W. 11 | Coll. Kraatz | Ohaus det." (DEI). 1 우 "Kinabalu, Borneo,1500m H.Rolle, Berlin S.W. 11 | Coll. Kraatz | Anomala

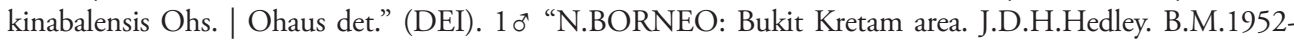
463.” (BMNH). $10^{\rightarrow}$ “N.BORNEO: Bukit Kretam area. J.D.H.Hedley. B.M.1952-463.” (BMNH).

\section{Diagnosis:}

Length. 9.1-10.5 mm; width. 5.2-6.2 mm. Anomala kinabalensis shares most morphological characters with $A$. felicia as described above. The inner limitation of the yellow lateral band of the pronotum is not notched but usually straight from anterior to posterior margin (Fig. 20), a character that is shared with $A$. snizeki, $A$. kaltengensis, $A$. bifida, $A$. aequalis and $A$. mahakamensis. From these five species, $A$. kinabalensis can only be distinguished by the shape of the aedeagus. Both, parameres and ventral plate are strongly elongate. The parameres are angled apically and bent downwards and are very similar to those of $A$. mahakamensis. The extension of the ventral plate is apically broader than in $A$. mahakamensis (Figs 11-12).

Distribution: Anomala kinabalensis is only known from the Kinabalu region in the province of Sabah (Fig. 22).

\section{Anomala mahakamensis sp. n.}

Holotype: ơ “Oost-BORNEO Sangasanga-dalem | coll. Zoölogisch Museum acq. 1938” (ZMAN).

\section{Description and Diagnosis:}

Length. $11.1 \mathrm{~mm}$; width. $6.9 \mathrm{~mm}$. Anomala mahakamensis shares most morphological characters with $A$. felicia as described above. With A. snizeki, A. kaltengensis, A. bifida, A. kinabalensis and $A$. aequalis it has in common a yellow lateral marking of the pronotum of which the inner limitation is not notched but usually straight from anterior to posterior margin (Fig. 20). From these five species, $A$. mahakamensis can only be distinguished by the shape of the aedeagus which is extremely similar to that of $A$. kinabalensis. Both, parameres and ventral plate are strongly elongate. The parameres are angled apically and bent downwards. The extension of the ventral plate is apically narrower than in A. kinabalensis (Figs 13-14). 

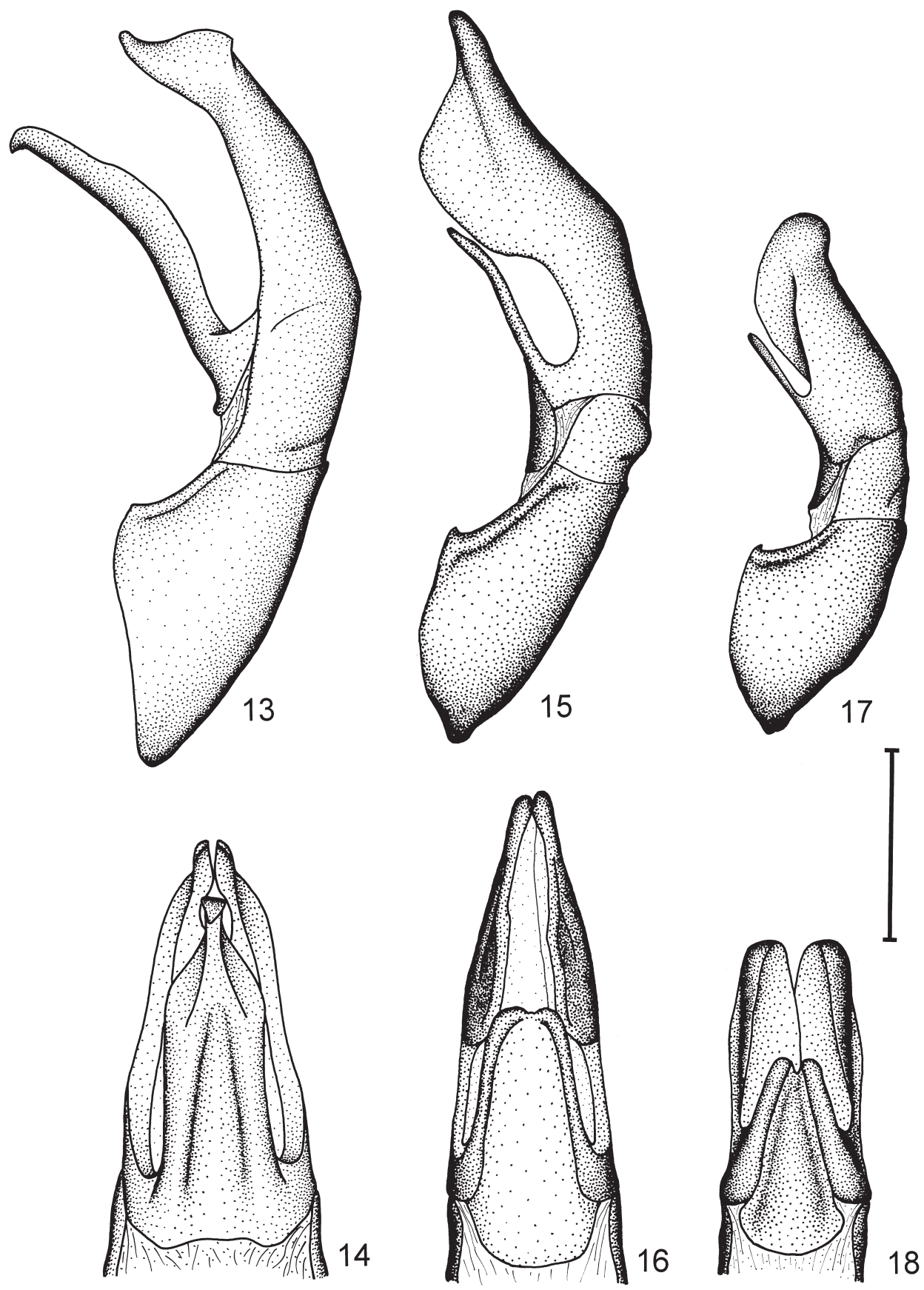

Figs 13-14: Aedeagus of Anomala mahakamensis (holotype); Fig. 13, lateral aspect; Fig. 14, ventral aspect. Figs 15-16: Aedeagus of Anomala manseri (holotype); Fig. 15, lateral aspect; Fig. 16, ventral aspect. Figs 17-18: Aedeagus of Anomala sarawakensis (syntype); Fig. 17, lateral aspect; Fig. 18, ventral aspect. scale $=1 \mathrm{~mm}$. 
Distribution: Anomala mahakamensis is only known from Sangasanga-dalam in the province of Kalimantan Timur (East Kalimantan) (Fig. 22).

Etymology: The new species is named after the Mahakam river in East Kalimantan.

\section{Anomala manseri sp. $\mathbf{n}$.}

Holotype: ${ }^{\star}$ „At light | SARAWAK: Gungong Mulu Nat. Oark [sic!] R.G.S. Exped. 1977-8 J.D. Holloway et al. B.M. 1978-206 | Site 1. January Camp 4, Mulu 1790m. 452463 Lower montane (moss) forest, MV - canopy“ (BMNH).

Paratypes: $10^{\star}$ „SARAWAK: Gunong Mulu Nat. Park R.G.S. Exped. 1977-8 J.D. Holloway et al. B.M. 1978-206 | Site 19. March W. Melinau Gorge 100m. 457567 Alluvial forest. Acl-understorey“ (CCZ). 1 \% „Old Secondary forest. | Native collected | SARAWAK: Foot of Mt. Dulit. Junction of rivers Tinjar \& Lejok. 6. x.1932. | Oxford Univ.Exp. B.M.Hobby \& A.W.Moore. B.M.1933254 | Ohaus determ. Anomala felicia Arr.? o “ (BMNH). $10^{\star}$, 1 ㅇ „Dr. J. Bosscha Sambas Borneo occ. | Mus. Leiden | Anomala kinabalensis Ohs. Cotype“ (NMHB, CCZ). $10^{\star}$ „Sarawak Baram R. Anomala sarawakensis Cotype Ohs.“ (NMHB). $20^{\star} 0^{\star}$, 5 ㅇ ․ㄹ. J. Bosscha Sambas Borneo occ. | Museum Leiden ANOMALA (A.) SARAWAKENSIS OHS.“ (CCZ, RMNH). 1 ○ „Dr. J. Bosscha Sambas Borneo occ. | Ohaus determ. Anomala sarawakensis Ohs." (RMNH).

\section{Description and diagnosis:}

Length. 9.5-10.4 mm; width. 5.5-6.1 mm. Anomala manseri shares most morphological characters with $A$. felicia as described above. The inner limitation of the yellow lateral band of the pronotum is strongly narrowed towards the posterior angle, a character that is only shared with A. sarawakensis (Fig. 21). Moreover, A. manseri and A. sarawakensis appear to be slightly larger than the other species of this complex, but too few specimens are available for final conclusions. From $A$. sarawakensis the new species can only be distinguished by the shape of the aedeagus. The parameres are much more elongated and pointed than in A. sarawakensis (Figs 15-16).

Distribution: Anomala manseri is known from the Baram River region in east Sarawak and Sambas in West Kalimantan (Fig. 22).

Etymology: This species is dedicated to Bruno Manser, a Swiss rain forest and human rights activist who is missing in Sarawak since 2000.

\section{Anomala sarawakensis OHAUs, 1910}

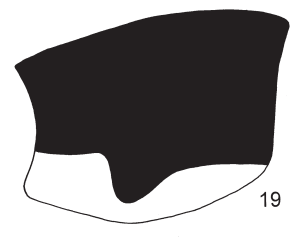

Anomala ovatula sarawakensis OHAus, 1910b: 216 [description]; OHAus 1916: 54 [Anomala sarawakensis]

Syntypes: $10^{\star}$ "Sarawak Mt. Penrissen 3300 ft. V. 1900 | Anomala sarawakensis Ohs. Type" (NMHB). $10^{*}$ "Penrissen May 1899 | ๆ | Typus | A. ovatula Ohs. sbsp. sarawakensis Ohs." (NMHB). 1 ㅇ "Penrissen May 1899 | ㅇ | Typus! | A. ovatula Ohs. sbsp. sarawakensis Ohs.” (NMHB).

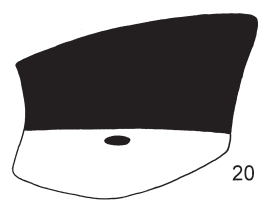

Note: In the collection of the NMHB are additional specimens labeled as "Cotypen" which are not mentioned in the original description and belong in fact to $A$. manseri.

Figs 19-21: Color pattern of pronotum, lateral aspect; Fig. 19, Anomala felicia; Fig. 20, Anomala snizeki; Fig. 21: Anomala manseri.

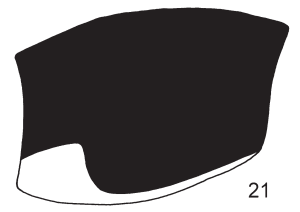




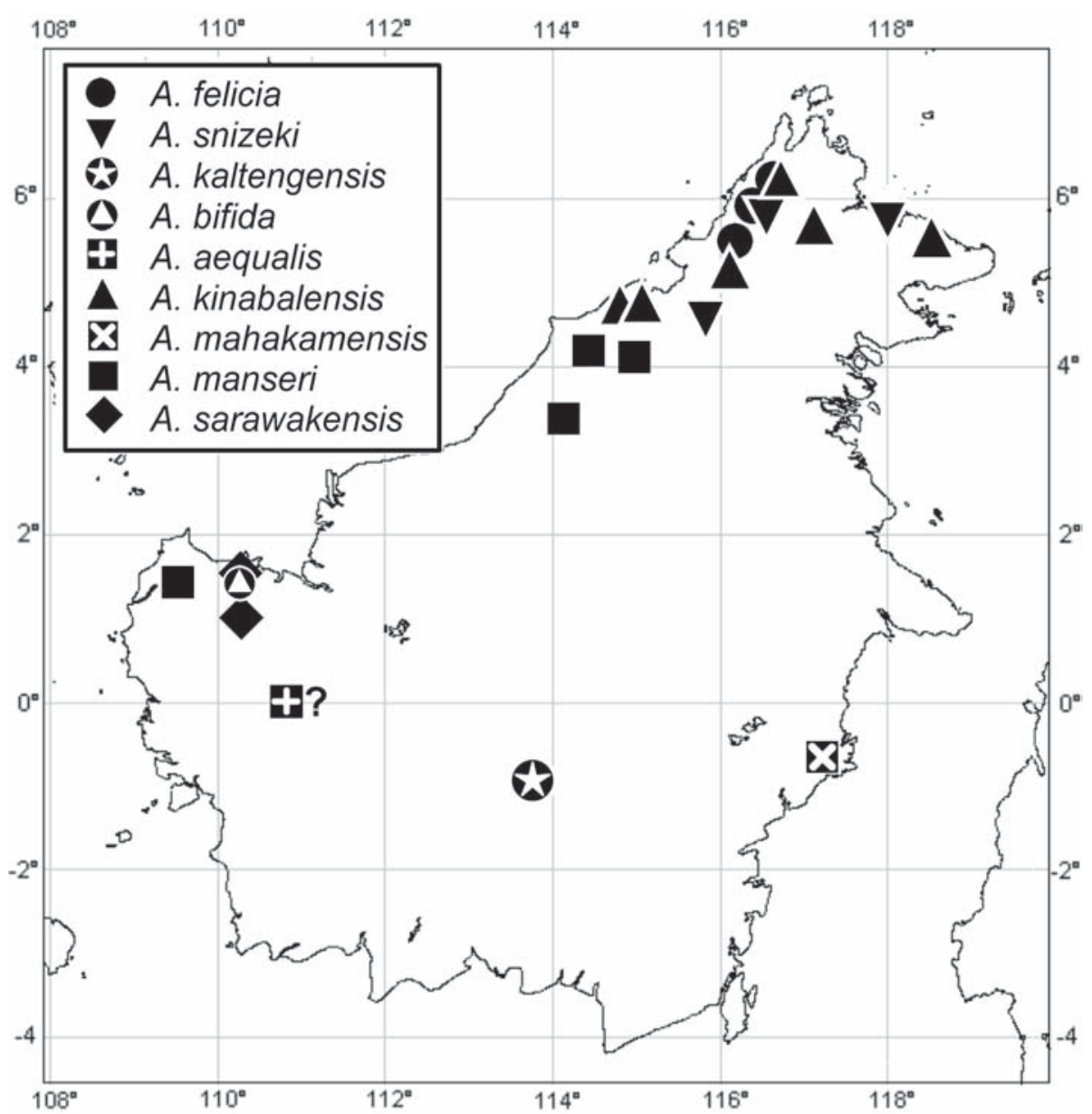

Fig. 22: Distribution map.

Additional material: $10^{\star}$ "Mt. Matang, W. Sarawak. G.E.Bryant.2.XII.13. | G. Bryant Coll. B.M.192686." (BMNH). $10^{*}$ "Mt. Matang, W. Sarawak. G. E. Bryant. 12. 11. 14. | Anomala felicia Arrow [sic!]” (NHMB).

\section{Diagnosis:}

Length. 10.5-11.5 mm; width. 5.9-6.5 mm. Anomala sarawakensis shares most morphological characters with $A$. felicia as described above. The inner limitation of the yellow lateral band of the pronotum is strongly narrowed towards the posterior angle, a character that is only shared with $A$. manseri (Fig. 21). Moreover, $A$. manseri and $A$. sarawakensis appear to be slightly larger in mean than the other species of this complex, but too few specimens are available for final conclusions. Anomala sarawakensis can only be distinguished from $A$. manseri by the shape of the aedeagus. The parameres are distinctly shorter than in $A$. manseri. The apex is somewhat bulged and not pointed (Figs 17-18).

Distribution: Anomala sarawakensis is only known from west Sarawak (Gunung Penrissen, Gunung Matang) (Fig. 22). One female from Mt. Lingga cannot be identified with certainty and belongs to $A$. sarawakensis, $A$. manseri or a yet unknown species. 


\section{Discussion}

The nine Anomala species from Borneo presented in this paper are extremely similar and can only be distinguished from each other with certainty by the shape of the aedeagus. Only $A$. felicia exhibits a species-distinctive coloration pattern. All species except $A$. felicia share a derived structure of the aedeagus with the ventral plate and parameres bearing conspicuous extensions. A. felicia, with a simple aedeagus, is considered to be part of this species-group because of the overall similarity and thus, it might represent the basal taxon. All known species seem to occur only on Borneo suggesting that speciation took place after Borneo was isolated from the Asian mainland. The relationship to the most similar species outside Borneo, Anomala porovatula OHAus 1915 and its relatives (ZoRN, 2000), is uncertain. The structure of the aedeagus of these species is simple, similar to that of $A$. felicia, but they show different coloration pattern and mostly a stronger punctation on the pronotum.

\section{Acknowledgements}

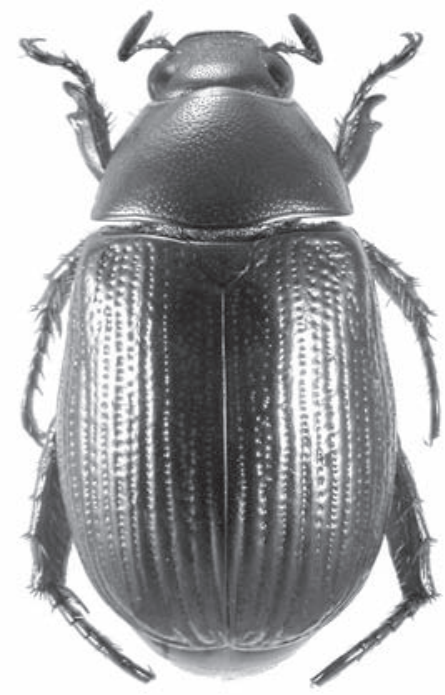

Fig. 23: Anomala felicia male.

I am greatly indebted to the following persons and institutions for providing access to their collections and for giving on loan type and unidentified material: Manfred Uhlig, Johannes Frisch, Berndt Jäger, Hella Wendt, Joachim Schultze (ZMHB); Ben Brugge (ZMAN); Jan van Tol, Rienk de Jong, Fred van Assen (RMNH); Malcolm Kerley (BMNH); Lothar Zerche, Lutz Behne (DEI); Jean Menier, Thierry Deuve, Olivier Montreul, Madame Tagavian (MNHN); Matthias Nuss, Olaf Jäger (MTD); Michel Brancucci and Eva Sprecher-Übersax (NHMB), Denis Keith, Chartres.

\section{Literature}

Arrow, G. J. 1910: On a few new Bornean Beetles of the Rutelid Genera Mimela and Anomala. - The Annals and Magazine of Natural History including Zoology, Botany and Geology (series 8) 4: 64-72.

Burmeister, H. 1844: Handbuch der Entomologie. 4 (1), Coleoptera Lamellicornia Anthobia et Phyllophaga systellochela. - Berlin: Enslin, ii + 587 pp.

Ohaus, F. 1910a: Die Ruteliden der Philippinischen Inseln. - The Philippine Journal of Science, D. General Biology, Ethnology and Anthropology 5: 233-262.

Ohaus, F. 1910b: Beiträge zur Kenntnis der Ruteliden. VII. - Annales de la Société Entomologique de Belgique 52: 213-227.

Ohaus, F. 1915: XVII. Beitrag zur Kenntnis der Ruteliden (Col. lamell.). - Stettiner Entomologische Zeitung 76: 88-143.

Ohaus, F. 1916: XVIII. Beitrag zur Kenntnis der Ruteliden (Col. lamell.). - Stettiner Entomologische Zeitung 77: 39-113.

Ohaus, F. 1938: XXX. Beitrag zur Kenntnis der Ruteliden (Col. Scarab.). - Stettiner Entomologische Zeitung 99: 258-272.

Zorn, C. 2000: Die Arten der Anomala porovatula OHaus-Gruppe von Sumatra (Coleoptera: Scarabaeidae: Rutelinae). - Beiträge zur Entomologie 50: 79-89. 